\title{
Territorial Manifestations in Times of Globalization: Implications for State- Centrism in International Relations
}

\author{
Boryana Aleksandrova \\ Sofia University "St. Kliment Ohridski" \\ Faculty of Law \\ Department of International Law and International Relations \\ e-mail: borjana_alexandrova@hotmail.com
}

\section{Abstract}

Globalization challenges the state-centric realist view of space and authority within International Relations. Using multifaceted concepts of territoriality and non-territoriality, this article goes into three versions of current territorial fragmentation or connectivity - deterritorialization, extraterritorialization and reterritorialization. They are to enable us to reveal the proliferation of globally relevant social and power dynamics above, below and within the state domain. At the same time, they are to illuminate the ambivalent role of states played in an era of global interconnectedness.

Keywords: globalization, territory, territoriality, realism, state-centrism, transnational, deterritorialization, extraterritorialization, reterritorialization.

1 The author extends her gratitude to Ms. Diana Stoyanova for her support in editing the English language of this article. 


\section{Introduction}

According to the still prevailing realist approach (Dunne and Schmidt) in the field of International Relations (IR) the national state has been understood as the primary actor on the world scene. Respectively, it has been theorized as a unitary political formation unaffected in its domestic juridical and power competences (Scholte, 20) and exercising control over a single physical territory. The conduct of international relations, in turn, has been conceived of in terms of state-centric geographical spaces and rules and logics (Stefanov, 18). The realpolitik interests and balancing of states against other states have thus long preoccupied the followers of realism (Grieco; Mingst, 70-79).

Today globalization questions the practicability and normativity of homogeneous state-oriented analytical constructs, in general, and their monolithic territorial epistemology (Jones, 241) in particular for the explanation of (inter)national life. Moreover, globalization "has a profound effect on the concept of physical territory as an organizing principle for social, cultural, economic, or political relations" (Ku and Yoo, 212). In fact, we are witnessing divergent expressions of territoriality and non-territoriality - see below -corresponding to different moments of state or non-state hegemonies, contestations and historical transformations. As a result, a lot of globally relevant developments are detected to occur across, within or independently, albeit not necessarily unrelatedly, of the territorial borders of state control.

This article outlines three versions of current territorial fragmentation or connectivity specifically revealing fractures in the Westphalian reading of the state's functioning - deterritorialization, extraterritorilization, reterritorialization. It constitutes an attempt to capture the complexities of contemporary power relations and further the discussion on the consequences of globalization for the operation of national states since the dawn of the 1980 os within IR. As such, the manuscript is interested in illuminating globalization as a historical challenge to the fundamental premises of realism. Why does the realist conception of the territorial state turn out to be insufficient to comprehend existent mechanisms of power and counterpower on various levels? How is the role of states to be looked upon in relation to globalization?

At the same time, this exposé does not pretend for exhaustion. It centers first and foremost on the territorial connotations of the problematic. It is considered beyond its scope to go deeper and broader into the wholesale IR debate between positivist and postpositivist theories on the topic. Nevertheless, the proposed considerations are thought to provide an impetus for further critical examination of one of the most dominant discourses in IR, that of the state and of state power, with regard to human existence and emancipation (Booth qtd. in Buzan and Hansen, 206). Drawing inspiration from anthropology (Follis), cultural studies (Appadurai; 
Deleuze and Guattari), geography (Scott) and sociology (Bauman; Beck; Castells, Eisenstadt; Sassen) for its methodology and conclusions, the article also strives to underline the need for more interdisciplinarity in the field of IR.

\section{(Non-)Territoriality versus Westphalian Territory}

Globalization appears as a process of "deepening, acceleration, and territorial extension of cross-border transactions in various areas of present life - economy, ecology, media, culture, social domain" (Menzel, 226). It has profoundly transformed modern societies and world order (Held et al., 7) through numerous embodiments of social connectivity and division, on the one hand, and of the interweaving between the two dynamics, on the other. Respectively, it has provoked numerous (inter)governmental and non-governmental, institutionalized and non-institutionalized agendas and discourses competing for presence or supremacy within and beyond states. As such, globalization poses a serious methodological dilemma for realism and its view of geopolitics predominantly as "a one-sided concern for the physical/military control of space" (Scott, 234), the latter interpreted by means of the Westphalian category of nonporous "state territory". This dilemma can be resolved by drawing on multivalent space conceptions, such as "territoriality" and "non-territoriality".

Leaning on Saskia Sassen (2006), the concept of "territoriality" can be referred to as the accumulation of potential for political influence based on the intertwining of multiple components - territory, authority, juridical rights, norms, technology, etc. Territoriality adopts "specific contents, shapes, and interdependences in each historical formation" (4). Correspondingly, the condition of "non-territoriality" can be understood to stem from a similar complex assemblage "detached from geographic territory but developed through the capabilities entailed by territoriality" (416). Therefore global geography is to be reconstructed by means of different territorial and non-territorial "assemblages on a global, national and sub-national level" (406), at least partially interpenetrating each other.

Notably, the spatial perspectives of territoriality and non-territoriality do not cast away states as irrelevant "world-cultural" terrains of authority and ruling capacities (Meyer et al., 157). Even more so, certain human activities remain primarily determined by national incentives (Stanford Encyclopedia of Philosophy). Speaking about the era of globalization, the notions of territoriality and non-territoriality are to serve us to investigate the relation between states and many other actors and factors on the (inter)national scene today -international organizations, supranational institutions, NGOs, social movements, identity politics, international law, human rights law, global capital and its organizational infrastructure, transnational crime and terrorism, etc. - in a more flexible and precise way. Indeed, state policies 
and institutions have been cultivating or accommodating significant elements of territorial fluidity. In this sense, three instantiations of (non-)territoriality will be operationalized in what follows. The three of them coexist, replenish or contend against each other in parallel.

\section{Deterritorialization}

Earlier employed as a term by Gilles Deleuze and Felix Guattari (1983) in their work on social and human reproduction in capitalism, in the framework of the methodology of (non-territoriality), chosen in this article, the condition of "deterritorialization" relates to processes, structures and dynamics that, at least partly, transpire the realist ontology of state behavior. Seen in light of the IR, "it is no longer self-evident that nation-states can be described as 'self-sufficient schemes for all the essential purposes of human life' in the context of the spread and intensification of social relations across borders" (Stanford Encyclopedia of Philosophy). Two of the most salient empirical instances of deterritorialization manifest themselves in the shape of global governance institutionalizations and the formation of digitally activated information, capital, image and social flows of trans-local significance since the beginning of the 1980s. Remarkably, institutionalizations of global governance have evolved on a governmental and non-governmental level - sometimes altering, sometimes outweighing national prerogatives.

Some thirty years after the end of the Second World War many intergovernmental and nongovernmental agencies started undergoing changes that gradually turned them into platforms of global governance (Varwick; Clark). Currently they are capable of adopting self-oriented working agendas, of maintaining selffulfilling normative discourses and of developing self-sanctioned practical and/ or legal tools. However, these instantiations of deterritorialization are not to be defined as completed or external to the states in an ultimate manner. At this historical moment their relevance for international relations is increasingly deriving from their direct or indirect effect on the domestic political, economic, social and cultural life of states. Furthermore, the endogeneous organizational coherence of states has been modified due to the autonomous activation of regulatory agencies within their administrative apparatuses (Jayasuriya, 426). A significant number of ministerial sections, central banks, etc. have been growing into mediators between the global and the national. They are correlating directly with similar counterparts on a governmental and non-governmental level - international financial institutions, consulting groups, stock exchanges, UN, etc. Concurrently, we see a process of "nationalization of international law" (Slaughter qtd. in. Jayasuriya, 440). Instead of replacing the state, international institutions and transnational networks rely on these new forms of "complex 
sovereignty" (426). By the same token, some forms of intertwining between state, inter-state and non-state rationalities seem to estrange citizens and their expectations (Crouch; Leggewi).

Two examples of governmental deterritorialization are the IMF and the WB. Both institutions came into being in 1944 in order to balance trade and financial deficits among industrialized states. While later expanding their lending to poor countries, their assistance became cumulatively disengaged from the idea of "securing political support for the donor countries" (Lundenstad, 258). In return their policies have been synchronizing more and more with the performance of global corporate bond markets (Stiglitz, Inequality, 213). Since the end of the 196os, the WB has engaged international private creditors in order to increase its capital, and the IMF began conditioning its loan guarantees on opening the recipient state's financial markets. This came along with an ideological shift in the management circles of the two bodies known as the "Washington consensus" - the preference for imposing deregulation, privatization and social restrictions on the part of indebted countries. From institutions adjusting inter-state trade and financial issues the IMF and the WB converted to quasi-autonomous regulators of national macroeconomic and social policies (Sassen, 152; Stiglitz, Discontents, 231-232) - at times potentiating the power of certain governmental elites, at times diminishing the position of others.

Analogously, under the banner of the doctrine "responsibility to protect" the UN Security Council is competent to initiate a military intervention in a state, without its permission, as long as it is not able or willing to manage genocidal conflicts within its national borders (ICISS; Weiss et al.). Further on, the UN Secretary General, the Executive Secretary of the UN Framework Convention on Climate Change, the Intergovernmental Panel on Climate Change and other environmental agencies are being instrumental for validating the climate discourse as a global normative stance. Finally, the jurisdiction of the International Criminal Court nominally extends over all party nationals.

The same concerns the rise of non-governmental institutionalizations of deterritorialization. The World Economic Forum counts among the most powerful ones. Its membership encompasses some of the world's most influential global economic and financial players. Governmental officials, well-positioned international figures, academic affiliates and NGOs attend the annual gatherings of the Forum in Davos, where global or regional matters are discussed. Transnational forums of experts like the annual Munich Security Conference serve as a focal point for the political, corporate, military and academic elites. All these instances of non-governmental deterritorialization differ from the normative and historical essence of traditional mechanisms for democratic participation of citizens within states but can influence the parameters of their existence. Similarly, the reactions of credit rating agencies like Standard\&Poor's, Moody's and Fitch to the results of national elections or other domestic affairs are functioning more and more as a paper for voters' future and well-being. 
Deterritorialization gets also fostered via a range of flows "of trillions of dollars, of information, of technology, of organizational interaction, of images, sounds, and symbols, mobilized under the combined effect of the communication technology and historical social processes" (Castells, Network Society, 401). The stream of transactions on the world stock markets, corporate tax heavens, global media channels, global elites of mobility (Bauman, 22-30) or global networks of human, arms and drugs trafficking belong to "the space of flows". Those flows penetrate and surpass the economic, cultural and political spaces demarcated by national borders. New patterns of social and economic flexibilities as well as hierarchies and asymmetries are getting underway. New coalitions between transnational and domestic political actors are forged (Cohen and Rai; Rosenau; Ghimire), repeatedly beyond electoral attendance both on the Left and on the Right (e.g. citizens' action committees, lobby groups, social movements, neighborhood vigilante patrols, etc.). The ideological and symbolic appeal of the national and revolutionary state's dominant models is waning at least partly (Eisenstadt).

\section{Extraterritorialization}

In order to countervail global challenges states also incline to extraterritorialize the satisfaction of their needs or their power grip. Hereby the concept of "extraterritorialization" incorporates all those political, diplomatic, administrative, economic, financial, police or military measures taken by governments for the purpose of strengthening their capabilities beyond their immediate jurisdiction. Extraterritorialization is an older form of instantiation of state territoriality but acquires new meanings in a global context and causes new effects, respectively, even to the extent of "denationalizing rather than producing an extension of national territorial authority" (Sassen, 419). Nowadays extraterritorialization takes place under multilayer social, economic, political, ecological and cultural circumstances that are difficult to reduce to rigid state space categories. Hence, it can be deciphered as a form of unilateral state regulation with manifold global implications. Current governmental policies in the area of migration and land use overseas as well as variable state regional undertakings can be traced to the evolution of globalization.

Meanwhile, the topic of migration occupies a substantive place in foreign and domestic affairs (Bardarov; IOM). Extraterritorialization in this sphere of state action implies projecting one-dimensional nationally underpinned standards over the existence and legal status of foreign citizens - outside and inside the officially designated frontiers of that state. In recent years it has confirmed itself as a tenacious endeavor for many governments to enact strict migration regimes with regard to certain categories of foreign persons and to coordinate them with 
other partners. In times of mutually interweaving natural and man-made pathologies (Follis, 118) with global repercussions, ambivalent classifications of migration and asylum statuses are being introduced to the benefit of well-educated, young, financially reliable and economically competitive individuals (Castells, Network Society, 132-133).

Gray zones of utilitarian or essentialist classifications of "suitable" and "unsuitable", "legal" and "illegal", "documented" and "undocumented" or ethnically and culturally "related" migrants and asylum-seekers come into being (Aleksandrova "Security in Times of Migration", "Europäische Dilemmata"). At the same time the exploitation of migrants' labor worldwide is on the rise (Taran and Geronimi, 3-4). National territories are being vigorously equipped with fortified state-ofthe-art border installations (Brown). Border technology is being reinforced along the US-Mexican border, a new fortified fence was built on the land border between Greece and Turkey, a wall between Kenya and Somalia is being raised, etc. The number of detention centers for asylum- or economic residence-seekers, including children and minors, is on the rise (Nethery and Silverman; UNHCR).

States display resoluteness to fund detention facilities for immigrants on neighboring territories. For example, under the so-called Australian Pacific Solution asylum-seekers are transferred to imprisonment centers in Nauru and Papua New Guinea after having reached the territory of Australia (Australian Human Rights Commission). The EU has been pursuing arrangements with its bordering countries (Ukraine, Serbia, Turkey) and Mediterranean neighbors (Libya, Morocco, Tunisia, Algeria and partly Egypt) for the interception, detention and processing of the cases of asylum-seekers on their respective territories (Global Detention Project). Malaysia is demonstrating an unwillingness to legalize the presence of tens of thousands of asylum-seekers from Myanmar, that have left their country in the last 50 years due to the rule of a military junta. Border patrolling is being carried out in extraterritorial waters. Trans-regional police cooperation on the selective prevention of migration is expanding. Ultimately, these policies are leading to the collective criminalization of whole groups of the world population. They are being dispossessed of their right to freedom of movement, of their right to subsistence, and of their right to security.

Simultaneously, states or state-sponsored corporations practice extraterritorialization while competing for global land resources - through land-renting and land-purchase, through subsidization of agricultural production and trade or through speculation with food prices (Le Monde Diplomatique, 18-19). In light of the climate change, the intensified production of biofuel, the financialization of land and food acquisition, and the forecasts for world population growth to 9 billion in 2050 mostly in developing countries, the worldwide demand increases for land for agriculture and stock breeding (Deininger and Byerlee; Kress; Borras et al.). Eventually, wasteful irrigation systems, ongoing inter-state 
water conflicts and water waste in industry are diminishing the possibilities for adequate land use as well - to the detriment of the most needy population. Among land-renting and land-purchasing countries, China, Japan, South Korea and Saudi Arabia come to the fore. Ethiopia, Thailand, Russia, Brazil, Ukraine, Cameroon, Laos and the Philippines, on the other hand, rank among the landleasing states (Land Matrix).

Similarly, many of the regional undertakings of states nowadays can be deemed as symptomatic for extraterritorialization under the banner of globalization. Both the Association Agreement negotiations between the EU and Ukraine and the Russian reaction to its expected signing since the end of 2013 are to be realized (and were overtly presented as such by Brussels and Moscow) as an aspiration towards gaining a competitive advantage on the global market. Substantially, the age of globality is an era of economically driven regional integration. Parallel to the enlargement of the European internal market, a series of accords lowering intra-regional tariffs and trade barriers are spreading all over the continents. A number of regional formations are established or upgraded, e.g. the common market MERCOSUR in Latin America, the free trade area within ASEAN, NAFTA and its expansion CAFTA to five Central American countries (Guatemala, El Salvador, Honduras, Costa Rica and Nicaragua) and the Dominican Republic, ECOWAS, AEC, etc. Apart from global resources' direct utilization and commercialization, states frequently invest in regional cooperation in the name of "global security". A whole range of open and undercover, legal and illegal, trans-border coordination activities among military and secret services are to be mentioned in this respect.

\section{Reterritorialization}

Another expression of territoriality is the phenomenon of reterritorialization. Going back to Deleuze and Guattari, "reterritorialization" in the perspective of IR can be articulated as an effort of "ancillary apparatuses, such as government bureaucracies and the forces of law and order" (35) as well as various social and political groups at a sub- and transnational level to reinstall homogeneous practices, norms and imaginaries in spaces which have previously been deterritorialized. Following David Newman, reterritorialization "involves both a process through which 'territorial configurations of power are continually ordered and reordered' as well as a continuous practice of differentiating and defining borders between societies according to specific criteria" (Newman qtd. in Scott, 235). It is a "constant process of reflecting group interests and identities against those of other groups in the world and through this reflection deriving principles for strategic action" (Scott, 235) by means of "ideology, discourses, political 
institutions, attitudes and agency" (Scott and Matzeit qtd. in Scott, 235). "These neoterritorialities are often artificial, residual, archaic; but they are archaisms having a perfectly current function, of sectioning off, of reintroducing code fragments, resuscitating old codes, inventing pseudo codes or jargons" (Deleuze and Guattari, 257).

An exemplary illustration of reterritorialization appears in the shape of refocusing formal and informal political discourses and practices upon the role of ethnic identity and demographics for the existence of a particular national population against the backdrop of constantly changing global social interrelationships. In that logic states reorganize their initiatives in appeal to - the wealthiest part of - the respective diaspora, consisting of "complex postnational social formations" (Appadurai, 254), or reinvigorate their projections over extraterritorial communities dubbed as historically belonging to the "ethnic composition" of the nation. The year 2000 saw the foundation of the State Agency for the Bulgarians Abroad. Its self-formulated priorities unequivocally refer to the unity of the so-called Bulgarian communities abroad, the educational advertising among the coming generation and the reincorporation of the qualified young Bulgarian migrants into the economic and political life of the country (State Agency). Since 2000 the Bulgarian government has been supporting the initiative "The Bulgarian Easter" in order to attract young Bulgarian professionals from abroad. The position of a Minister for the Bulgarians Abroad was created between 2009 and 2011. In 2012 the Ministry of Economic Affairs of the German State of Bavaria brought into existence the initiative "Return to Bavaria". The latter was meant to reinforce the pool of globally competitive professionals in Germany. Accordingly, the NGO "German Scholars Organization" was instructed to approach German university graduates overseas and support them on their return back to the country (Wisdorff). Without neglecting the long-standing geopolitical and geocultural traditions in states' policies of migration, the reterritorializing effect of these policies in the era of intensifying globalization is not to be underestimated.

On the other hand, different varieties of group autonomies, identities and collective rights are being reconstructed or reinvented (Eisenstadt). This development, in concurrence with central authorities' proneness to delegate certain prerogatives to local administrations for dealing with global challenges (Castells, Identity, 242), accounts for the reemergence of the minority problematic (Eisenstadt). In addition reterritorilization is gaining a foothold in the face of increasing anti-migrant moods from South Africa through Thailand, Malaysia and Russia to the EU members. Ultimately, its repercussions are to be retraced in the signaled motivations and power claims of sprouting terrorist organizations that have been joining the global flows of information, technology, finances and social exchange since the beginning of the twenty-first century. 


\section{Conclusion}

Globalization is shaking the historical underpinnings and, for that matter, the social and normative substantiations of existing state-centric territorial orders of power. Respectively, the rigid state-related notion of territory of realism turns out to be inapt to encompass current spatial complexities. Alternatively, the more differentiated cross-cut conceptions of territoriality and non-territoriality, as introduced earlier in this manuscript, can be used to overcome those epistemological gaps.

Put into this perspective, globalization brings with it a multiplicity of governmental and non-governmental, formal and informal, public, private and publicprivate territorialities or non-territorialities. A number of forces now combine to decouple "the political" from the categorical framework of the national state, even "from the standard roles associated with political and non-political actions" (Beck, 38). These (non-)territorialities can be regrouped under three main headings, viz. deterritorialization, extraterritorialization and reterritorialization. Deterritorialization finds its embodiment, among other things, in the consolidation of intergovernmental and non-governmental institutionalizations of global governance. It is also an expression of the formation of technologically moved flows of capital, information, migration, trafficking, weapons, etc. as well as the insertion of states' political, organizational and legislative spaces by these flows. Concurrently, governments are extraterritorializing their capacities for meeting globally related interests beyond their own jurisdictions. Reterritorialization, on its part, yields the proclivity of states or, respectively, sub- and transnational formations to reintroduce elements of Westphalian order in spaces having been disaggregated erstwhile by the power of the flexible transterritorial flows.

Yet, in their majority, all these manifold territorial manifestations are still relating to the attributes of state power and organization. States are not disappearing completely from the international scene. Although some of their rationalities are retaining their Westphalian character, there is a strong tendency that the purpose and meaning of national governance is "being reconstituted and restructured in response to the growing complexity in a more interconnected world" (Rosenau qtd. in Held et al., 9) as well. As it was discussed above, states represent one of the many terrains of global life while continuously interacting with other international actors and factors. In reality, measured in the categories of (non-)territoriality, they function as an important agent for the evolution of globalization and its technological, economic, social and political inequalities among the world populations. This conclusion is to enable us to reveal the ambiguous role played by states in the face of globalization.

Such kind of interpretations should lead us beyond the dualistic inquiry of globalization as a phenomenon "outside of the state" resulting in "more or less sovereignty". Indeed, although state territory still matters, the geography of world politics is now no longer reducible to fixed border constellations (Rosenau, 85-86). 
At the very least, firm steps should be undertaken to analyze the international relations as inter-societal (Czempiel, 7) and the international politics - as transnational as well, beyond the monolithic parameters of realism.

\section{Works Cited}

Aleksandrova, B. Security in Times of Migration. Towars a Glocal Definition and Practice of Security. The Case of the Syrian Refugees in Bulgaria. "Balkan Social Science Review", no. 4 (2014), pp. 227-253.

Appadurai, A. Modernity at Large: Cultural Dimensions of Globalization. Bulgarian Translation. Sofia: LIK, 2006.

Australian Human Rights Commission. Transfer of Asylum Seekers to Third Countries. Web. 1 Jan. 2014, https:/www.humanrights.gov.au/our-work/ asylum-seekers-and-refugees/projects/transfer-asylum-seekers-third-countries.

Bardarov, G. Immigration, Conflicts and Transformation of Identities in the Euroepan Union. Sofia: Edikta, 2015.

Bauman, Z. Globalization: the Human Consequences. New York: Columbia Univesity Press. Bulgarian Translation. Sofia: LIK, 1999.

Beck, U. Risikogesellschaft. Auf dem Weg in eine andere Moderne. Bulgarian Translation. Sofia: K\&H, 2013.

Borras, Saturnino M. et al. Towards Understanding the Politics of Flex Crops and Commodities: Implications for Research and Policy Advocacy. "Think Piece Series on Flex Crops\&Commodities”, no. 1. Amsterdam: Transnational Institute, 2014.

Brown, V. The Reflectivist Critique of Positivist IR Theory. Web. 27 Feb. 2011, http:// www.e-ir.info/2011/02/27/the-reflectivist-critique-of-positivist-ir-theory.

Brown, W. Walled States. Waning Sovereignty. New York: Zone Books, 2010.

Buzan, B., and Hansen, L. The Evolution of International Security Studies. New York: Cambridge University Press, 2010.

Castells, M. The Rise of the Network Society. “The Information Age: Economy, Society and Culture", vol. 1. Bulgarian Translation. Sofia: LIK, 2004.

Clark, I. Globalization and the Post-Cold War Order, [in:] The Globalization of World Politics. An Introduction to International Relations, eds. J. Baylis, S. Smith. Oxford: Oxford University Press, 2001.

Cohen, R., and Rai, S.M. Global Social Movements: Towards a Cosmopolitan Politics, [in:] Global Social Movements, eds. R. Cohen, S.M. Rai. London: The Athlone Press, 2000.

Crouch, C. Postdemokratie. Fr/M: Suhrkamp, 2013.

Czempiel, E-O. Weltpolitik im Umbruch. München: C.H.Beck, 2002.

Deininger, K., and Derek B. Rising Global Interest in Farmland: Can it Yield Sustainable and Equitable Benefits? Washington: The World Bank, 2011. 
Deleuze, G., and Guattari, F. Anti-Oedipus: Capitalism and Schizophrenia. Minneapolis: University of Minnesota Press, 1983.

Dunne, T., and Schmidt, B.C. Realism, [in:] The Globalization of World Politics. An Introduction to International Relations, eds. J. Baylis, S. Smith, P. Owens. Oxford: Oxford University Press, 2013.

Eisenstadt, S. The Contemporary Globalization, Hegemonies and Transformations of the National States. "The Culture Magazine”, no. 23 (2012), pp. 10-11.

Europäische Dilemmata vor dem bulgarischen Grenz- und Einwanderungsregime. "Zeitschrift für Außen- und Sicherheitspolitik", no. 2 (2015), pp. 209-220.

Follis, K. Building Fortress Europe. The Polish-Ukranian Border. Philadelphia: The University of Pennsylvania Press, 2012.

Global Detention Project. The Detention of Asylum Seekers in the Mediterranean Region. “Backgrounder". Web. April 2015, http://www.refworld.org/pdfid/556736e24.pdf>.

Ghimire, K.B. The Contemporary Global Social Movements: Emergent Proposals, Connectivity and Development Implications. UNRISD Program Civil Society and Social Movements, "Working Paper”, no. 19 (15 Aug. 2005). Web. 17 Dec. 2016, http://www.unrisd.org/unrisd/website/document.nsf/\%28httpPublications\%29/ F0F8C2DF84C2FB2DC1257088002BFBD9?.

Grieco, J.M. Realist International Theory and the Study of World Politics, [in:] New Thinking in International Relations Theory, eds. M.W. Doyle and G.J. Ikenberry. Boulder, Co: Westview Press, 1997.

Held, D. et al. Global Transformations: Politics, Economics and Culture. Stanford: Stanford University Press, 1999.

ICISS. The Responsibility to Protect. Ottawa: International Development Research Centre, 2001.

IOM. World Migration. Web. https://www.iom.int/world-migration.

Jayasuriya, Kanishka. Globalization, Law, and the Transformation of Sovereignty: The Emergence of Global Regulatory Governance. "Indiana Journal of Global Legal Studies", no. 2 (1999), pp. 425-455.

Jones, A. Globalization: Key Thinkers. Cambridge\&Malden: Polity Press, 2010.

Kress, D. Investitionen in den Hunger? Land Grabbing und Ernaehrungssicherheit in Subsahara-Afrika. Wiesbaden: Springer Verlag, 2012.

$\mathrm{Ku}, \mathrm{J}$. , and Yoo, J. Globalization and Sovereignty. "Berkeley Journal of International Law”, no. 1 (2013), pp. 210-234. Web. http://scholarship.law.berkeley.edu/bjil/ $\operatorname{vol} 31 /$ iss1/6.

Land Matrix. http://landmatrix.org/en/.

Leggewie, C. Transnational Movements and the Question of Democracy. Web. 3 Febr. 2003, http://www.eurozine.com/articles/2003-02-03-leggewie-en.html.

Le Monde Diplomatique. Atlas der Globalisierung: sehen und verstehen, was die Welt bewegt. Lahr: Druckhaus Kaufmann, 2009. 
Menzel, U. Zwischen Idealismus und Realismus: Die Lehre von den Internationalen Beziehungen. Fr/M: Suhrkamp Verlag, 2001.

Meyer, J.W. et al. World Society and the Nation State. "American Journal of Sociology", no. 1 (1997), pp. 144-181.

Mingst, K. Essentials of International Relations. NY: W. W. Norton\&Co, 1998.

Nethery, A. and Silverman, S.J. (eds.). Immigration Detention: The Migration of a Policy and Its Human Impact. Oxon \& New York: Routledge, 2015.

The Power of Identity. "The Information Age: Economy, Society and Culture", vol. 2. Bulgarian Translation. Sofia: LIK, 2006.

Rosenau, J.N. Distant Proximities: Dynamics Beyond Globalization. Princeton: Princeton University Press, 2003.

Sassen, S. Territory, Authority, Rights: From Medieval to Global Assemblages. Princeton\&Oxford: Princeton University Press, 2006

Scholte, J.A. The Globalization of World Politics, [in:] The Globalization of World Politics. An Introduction to International Relations, eds. J. Baylis, S. Smith. Oxford: Oxford University Press, 2001.

Scott, J.W. Bordering and Ordering the European Neighbourhood: A Critical Perspective on EU Territoriality and Geopolitics. "Trames", no. 3 (2009), pp. 232-247. Web. http://www.kirj.ee/public/trames_pdf/2009/issue_3/trames-2009-3-232-247.pdf.

Stanford Encyclopedia of Philosophy. Globalization, 10 Jun. 2014. Web. 17 Dec. 2016, https://plato.stanford.edu/entries/globalization/.

State Agency for the Bulgarians Abroad. "Priorities." Web. 17 Dec. 2016, http://www. aba.government.bg/?show $=14$.

Stefanov, G. Theory of International Relations. Sofia: Ciela, 2004.

Stiglitz, J. Globalization and its Doscontents. New York: Northon\&Company. Bulgarian Translation. Sofia: University Publishing House "Stopanstwo", 2014.

Stiglitz, J. The Price of Inequality: How Today's Divided Society Endangers Our Future. New York: Northon\&Company. Bulgarian Translation. Sofia: Iztok-Zapad, 2014.

Taran, P.A., and Eduardo Geronimi. Globalization, Labour and Migration: Protection is Paramount. ILO. Working Paper. 11 Dec. 2013. Web. 17 Dec. 2016, http://www. ilo.org/global/topics/labour-migration/publications/WCMS_232365/lang--en/ index.htm.

UNHCR. Detention. Web. 17 Dec. 2016, http://www.unhcr.org/detention.html.

Varwick, J. Globalisierung, [in:] Handwörterbuch Internationale Politik, ed. W. Woyke. Opladen: Leske+Budrich, 2000.

Weiss, T.G. et al. The Responsibility to Protect: Challenges \& Opportunities in Light of the Libyan Intervention. e-International Relations book, 2011. Web. 17 Dec. 2016, http://www.e-ir.info/wp-content/uploads/R2P.pdf.

Wisdorff, F. Warum deutsche Auswanderer zurückkommen. "Die Welt", 29 Sept. 2013. Web. http://www.welt.de/wirtschaft/article120487744/Warum-deutscheAuswanderer-zurueckkommen.html. 
Boryana Aleksandrova - PhD (University of Münster, Germany, 2008); Senior Assistant-Professor in International Relations, Sofia University "St. Kliment Ohridski", Bulgaria (2010-2018); Interdisciplinary Research Colloquium "Border Studies and Critical Migration Research", Interdisciplinary Research Center "Border Crossings - Crossing Borders", Humboldt University of Berlin (2018- ); current research interests: theory of international relations, globalization, war and peace, international politics; teaching: university course "Globalization and International Relations"; seminars on Theory of International Relations, Theory of Foreign Policy, Theory of International Negotiations; introductory seminar on International Relations for students of law. 